\title{
Two new species of Cyperus (Cyperaceae) from Brazil
}

\author{
Gordon C. Tucker ${ }^{1}$
}

\begin{abstract}
Two new species of Cyperus L. (Cyperaceae), both from Brazil, are described and compared to near relatives. Cyperus hooperae is described from two collections from the Chapada do Veadeiros in the State of Goiás; it is most similar to C. refractus of the southeastern U.S. Cyperus thomasii is described from a single collection from the municipality of Caruaru in Pernambuco; it is most similar to C. granatensis of Colombia. Following IUCN standards, both are considered threatened.
\end{abstract}

Key words: Brazil, Pernambuco, Goiás, Chapada dos Veadeiros, Caruaru

\section{Introduction}

The genus Cyperus L. includes about 800 species, occurring worldwide in warm temperate and tropical regions (Larridon et al. 2011a, 2011b). The distribution of individual species ranges from cosmopolitan, e.g. C. squarrosus L. and C. odoratus L., to regional and narrow endemics found on all continents except Antarctica (Kükenthal 1935-36; Tucker 1994, 2001). In the New World, areas of high diversity and endemism include the southeastern United States, Mexico, the Greater Antilles, and eastern Brazil (Tucker 2007).

\section{Materials and Methods}

This paper represents a contribution toward a monograph of the approximately 225 Neotropical species of Cyperus. As part of this study, the author has examined approximately 40,000 specimens since 1980 from the herbaria listed in the Acknowledgements. While examining unidentified South American specimens of Cyperaceae in the herbaria of the Missouri Botanical Garden, the New York Botanic Garden, and several other institutions, the collections below were recognized as belonging to two undescribed species. Provisional IUCN conservation assessments were made for the three species discussed herein, using IUCN (2001) criteria.

\section{Results and Discussion}

Cyperus hooperae G.C. Tucker, sp. nov. Type: BRAZIL. Goiás: Chapada dos Veadeiros, $20 \mathrm{~km}$ N of Alto Paraiso, 1600 m, 6.III.1973, fr., W.R. Anderson 6478 (holotype NY, isotypes MO, NY).
Cespitose perennial, 100-150 cm tall. Rhizome about $5 \mathrm{~mm}$ long, 2-4 mm thick, indurate, oblique. Culms $2-2.5 \mathrm{~mm}$ in diameter, trigonous, smooth. Leaves 6-7, sheaths reddish basally; blades $40-70$ $\mathrm{cm}$ long, 5-8 $\mathrm{mm}$ wide, $\mathrm{v}$-shaped, the margins and veins below scabrous. Inflorescence bracts $6-7$, $8-20 \mathrm{~cm}$ long, 2-5 mm wide, vshaped, the margins and keel scabrellate, horizontal to ascendent at $45^{\circ}$; secondary bracts $1.2-2 \mathrm{~cm}$ long. Rays 3-6, 1-11 cm long; prophylls 5-7 mm long, truncate, reddish distally; secondary rays none. Spikes $1(-3), 20-30$ $\mathrm{mm}$ long, 18-20 mm wide, loosely cylindric; rachis visible between bases of spikelets when pressed, $15-25 \mathrm{~mm}$ long (spikelets about $12-15$ per $\mathrm{cm}$ ). Spikelets $25-30,7-10 \mathrm{~mm}$ long, $0.8-1 \mathrm{~mm}$ wide, linear-lanceolate, terete; bract narrowly deltate to linear-lanceolate, 1.5-2 mm long; prophyll ovate, about $2 \mathrm{~mm}$ long; rachilla deciduous, about 0.3 $\mathrm{mm}$ wide and $0.1 \mathrm{~mm}$ thick, flexuous, green, the wings about $0.3 \mathrm{~mm}$ wide, hyaline, successive scales about $4 \mathrm{~mm}$ apart on same side of rachilla. Scales persistent, appressed and somewhat involuteclasping, 1-2, 4.5-5 mm long, 1.2-1.4 mm wide, oblonglanceolate, \pm obtuse, mucronulate, involute, laterally 2-3 nerved, offwhite to light brown, red speckled, medially green, 3(-5) nerved. Stamens 3; filaments $3.64 .5 \mathrm{~mm}$ long; anthers $2.5-2.7 \mathrm{~mm}$ long, linear, the connective apex ca. $0.1 \mathrm{~mm}$ long, reddish. Styles 1-2 mm long; stigmas 3, 3-4 mm long. Achenes about $3 \mathrm{~mm}$ long, $0.65-0.7 \mathrm{~mm}$ wide, trigonous, narrowly, the apex acute, apiculate from the dark purple style base, the stipitate base 0.1 $-0.2 \mathrm{~mm}$ long, about $0.2 \mathrm{~mm}$ wide, the adaxial face convex, the abaxial flat, the surface papillose, brown. 
Geographical Distribution: The species is known from two collections, located at sites within Parque Nacional Chapada dos Veadeiros. Although this is a protected area, IUCN status of Endangered B1a is still indicated (IUCN 2001), because the new species is "known to exist at no more than five locations."

Habitat: cerrado on sandstone, in seeping hillsides, creek margins, and rocky slopes.

Phenology: The type, collected in March, has mature achenes and disarticulating spikelets, while the other known collection, made in February, has stigmas exserted, but stamens still enclosed by scales.

Additional specimen: Brazil: GoIÁs: ca. $30 \mathrm{~km}$ NW of Veadeiros, 1000 m, 16.II.1966, H.S. Irwin et al. 12969 (NY).

Discussion: Cyperus hooperae is named for Sheila S. Hooper (b. 1925), retired curator at the Royal Botanic Gardens, Kew, and specialist on Cyperaceae. The new species (Fig. 1) finds it place in C. sect. Umbellati C.B. Clarke, characterized by the rachilla and spikelets deciduous; spikelets typically producing only 1-2(-3) achenes; and, scales involute, surrounding achenes. The narrow, slender spikelets with widely spaced floral scales (4 $\mathrm{mm}$ apart on the same side of the rachilla) contrast with other species of this section. Notably, the size of the anthers is larger than in any other species of the section; the only ones coming close are C. picardae Boeck. of Hispaniola, and $C$. diamantinus (D.A. Simpson) Govaerts \& D.A. Simpson, of eastern Brazil. A comparison of the differences among these species is provided in Table 1. Using the treatment of Kükenthal (1935-1936), this new species would key to C. picardae.

Cyperus thomasii G.C. Tucker, sp. nov. Type: BRAZIL. Pernambuco: Caruaru, Brejo dos Cavalos, Fazenda Caruaru, $08^{\circ} 18^{\prime} \mathrm{S}, 36^{\circ} 00^{\prime} \mathrm{W}, 1100 \mathrm{~m}$, 23.II.1994, fl. e fr., S.I. Silva s.n. (holotype: NY 00602928; isotype: MO 5905447).

Culms solitary, $25-31 \mathrm{~cm}$ tall, 2-2.3 mm wide, trigonous, smooth. Roots fibrous; rhizome horizontal, $2+\mathrm{cm}$ long, $3-5 \mathrm{~mm}$ wide, covered with fibrous remains of scales. Leaves 3-4, 10-20 cm long, 3-7 $\mathrm{mm}$ wide, inversely $\mathrm{W}$-shaped, veins average $0.1 \mathrm{~mm}$ apart, smooth except for prickles on margins. Bracts 4-5, horizontal to ascendent at $30^{\circ}, 5-22 \mathrm{~cm}$ long, 1.5-6 mm wide (longest bract 5-7 times longer than longest ray), inversely $\mathrm{W}$-shaped, the margins and main veins scabrellate; secondary bracts about $1 \mathrm{~cm}$ long. Rays 4-5, 0.5-3 cm long; prophylls 7-8 mm, truncate, reddish. Spikes $1-3$, broadly pyramidal, 20 $25 \mathrm{~mm}$ long, 30-40(-45) mm wide; rachis 6-12 mm long, with 7-9 spikelets per $\mathrm{cm}$. Spikelets divergent, 4-10, linear-lanceolate, compressed (flat-ellipsoid in cross-section), 15-25(-30) mm long, 1.7-2 mm wide; rachilla tardily deciduous, dark brown to blackishbrown, flexuous, slightly geniculate, its wings hyaline, $0.3 \mathrm{~mm}$ wide; successive scales $2.4-2.6 \mathrm{~mm}$ apart. Scales persistent, 10-24, slightly spreading, deltate, acute, mucronulate, 3-3.6 mm long, 1.6-2 mm wide, laterally reddish, 2-nerved near midvein, medially greenish, 3-nerved. Stamens 3; filaments 3-3.5 mm long; anthers 1.6-2.1 mm long, the connective apex red, about $0.1 \mathrm{~mm}$ long. Styles 0.6-1 mm long; stigmas $3,1-2 \mathrm{~mm}$ long. Achenes trigonous, broadly oblongellipsoid, $1.2 \mathrm{~mm}$ long (about $0.35 \times$ as long as scale), 0.6-0.7 $\mathrm{mm}$ wide, apiculate, the base substipitate to cuneate, the adaxial face concave, the abaxial faces convex, puncticulate, brown.

Geographical Distribution: Endemic to Pernambuco, in northeastern Brazil. Only the type specimen is known. No additional specimens have been seen. For this reason, IUCN status of Endangered B1a is indicated (IUCN 2001), because it is "known to exist at no more than five locations."

Habitat: Evidently in a swamp or marsh, but not explicitly recorded on labels, which has the heading "Brejos de Altitude do Pernambuco."

Phenology: Probably January to March. The type specimen, collected in February, includes spikelets just past anthesis (but with some dehiscent anthers) and some spikes with mature or nearly mature achenes.

\section{Discussion}

Cyperus thomasii is named for William Wayt Thomas (b. 1951), curator at the New York Botanical Garden, dedicated conservationist, and specialist on Cyperaceae, especially of Brazil (Alves et al. 2007). This new species (Fig. 2) finds its place in $C$. sect. Subquadrangulares Kük., species of which are characterized by broadly ovate spikes, with spikelets compressed-subquadrangulate. The rachilla is flexuous and winged, and the scales remote, elliptic, obtuse, 7-11 nerved. Anthers are oblong to linear, with connective apex scarcely prolonged, and the achene $1 / 3-1 / 2$ as long as scale, elliptic or oblong. The section has about 12 species, and occurs in Africa, southern and SE Asia, and tropical America. The new species is morphologically most similar to Cyperus granatensis C.B. Clarke, a rare (perhaps extinct) endemic species from Colombia. There are also some similarities to C. gracilinux of central and West Africa. Another widespread Neotropical and African species of this section, C. sphacelatus Rottb., is an annual. Comparisons of related species are made in Table 2. 
Table 1 - Comparison of Cyperus hooperae with related species; all measurements in mm

\begin{tabular}{lccc}
\hline Species/Character & Cyperus diamantinus & Cyperus hooperae & Cyperus picardae \\
\hline Leaf width & $1-6$ & $5-8$ & $1.5-2$ \\
Spikelet orientation & All spreading & $\begin{array}{c}\text { Spreading, the lowermost } \\
\text { slightly reflexed }\end{array}$ & $\begin{array}{c}\text { Terminal spikelet erect, the } \\
\text { others strongly reflexed }\end{array}$ \\
Spikelet length & $4-7$ & $7-10$ & 8 \\
Spikelet width & 1 & $0.8-1$ & $0.6-0.8$ \\
Scale separation & $1.7-2.4$ & 4 & 2 \\
Scale length & $3-4.5$ & $4.5-5$ & $5-6.5$ \\
Scale width & 1.32 .0 & 1.21 .4 & 1.41 .5 \\
Scale apex & Slightly mucronulate & Mucronulate & Cuspidate \\
Scale color & Dark reddish brown, & Off-white to light brown, & Brownish \\
Anther length & the margins hyaline & red speckled & 2.0 \\
Achene length & $2-2.3$ & 2.7 & $3.5-3.8$ \\
Achene width & $2-2.7$ & 3 & 0.5 \\
\hline
\end{tabular}

Table 2 - Comparison of Cyperus thomasii with related species; all measurements in mm.

\begin{tabular}{|c|c|c|c|c|}
\hline Species/character & Cyperus gracilinux & Cyperus granatensis & Cyperus sphacelatus & Cyperus thomasii \\
\hline Underground parts & Stoloniferous & Missing from type & no rhizome & Rhizome present \\
\hline Bract orientation & Ascendant at $45-60^{\circ}$ & Ascendant at $75^{\circ}$ & $\begin{array}{c}\text { Horizontal to } \\
\text { ascendent at } 45^{\circ}\end{array}$ & $\begin{array}{c}\text { Horizontal to ascendent } \\
\text { at } 30^{\circ}\end{array}$ \\
\hline $\begin{array}{l}\text { Longest bract } \\
\text { length/longest ray }\end{array}$ & $2-3$ times longer & 2 times longer & 4 times longer & 5-7 times longer \\
\hline Spikelet orientation & Spreading & Suberect-ascendent & Spreading & Spreading \\
\hline Spikelet length & $16-24$ & $11-17$ & $17-20(-35)$ & $15-20$ \\
\hline Spikelet width & 2 & $3-3.5$ & $(1.2-)$ 1.4-2.0 & $1.7-2$ \\
\hline Scale separation & Ca. 1 & $3.2-3.5$ & $1.5-1.75$ & $2.4-2.6$ \\
\hline Scales length & $2.5 /$ & $4.8-5.2$ & $3.0-4.0(-4.4)$ & $3-3.6$ \\
\hline Scale width & Ca. 1 & $2.5-2.8$ & $1.8-2.2$ & $1.6-2$ \\
\hline Scale shape & Elliptic & $\begin{array}{l}\text { Ovate, obtuse, hardly } \\
\text { keeled, }\end{array}$ & Elliptic, sub-acute & $\begin{array}{c}\text { Deltate, acute, } \\
\text { mucronulate }\end{array}$ \\
\hline Scale color & Reddish brown & $\begin{array}{l}\text { Uniformly dark brown } \\
\text { to castaneous }\end{array}$ & $\begin{array}{l}\text { Pale green with dark } \\
\text { red lateral splotch }\end{array}$ & $\begin{array}{l}\text { Laterally reddish, } \\
\text { medially greenish }\end{array}$ \\
\hline Anther length & $0.7-0.8$ & 2.2 & about 0.6 & $1.5-2$ \\
\hline Achene length & 2.0 & 2.0 & $1.4-2.0$ & 1.2 \\
\hline Achene width & 0.7 & $0.9-1.1$ & $0.6-0.9$ & 0.7 \\
\hline Achene shape & Narrowly ellipsoid & Oblong-ovoid & Narrowly ellipsoid & Broadly oblong-ellipsoid \\
\hline
\end{tabular}




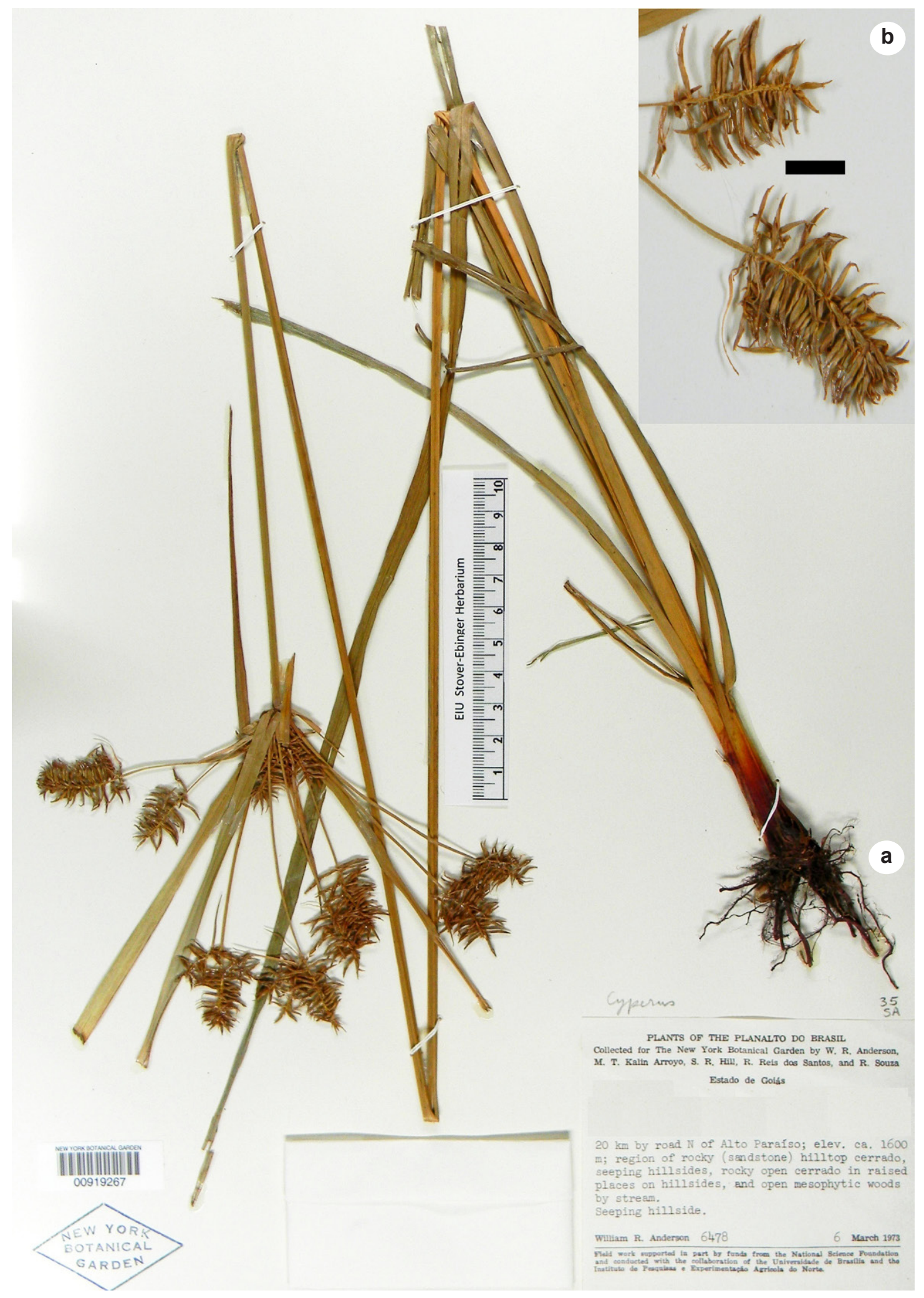

Figure 1 - Cyperus hooperae G.C. Tucker, sp. nov. - a. habit; b. upper right, two spikes (bar $=5 \mathrm{~mm}$ ); from W.R. Anderson et al. 6478 (NY), from Goiás, Brasil. 


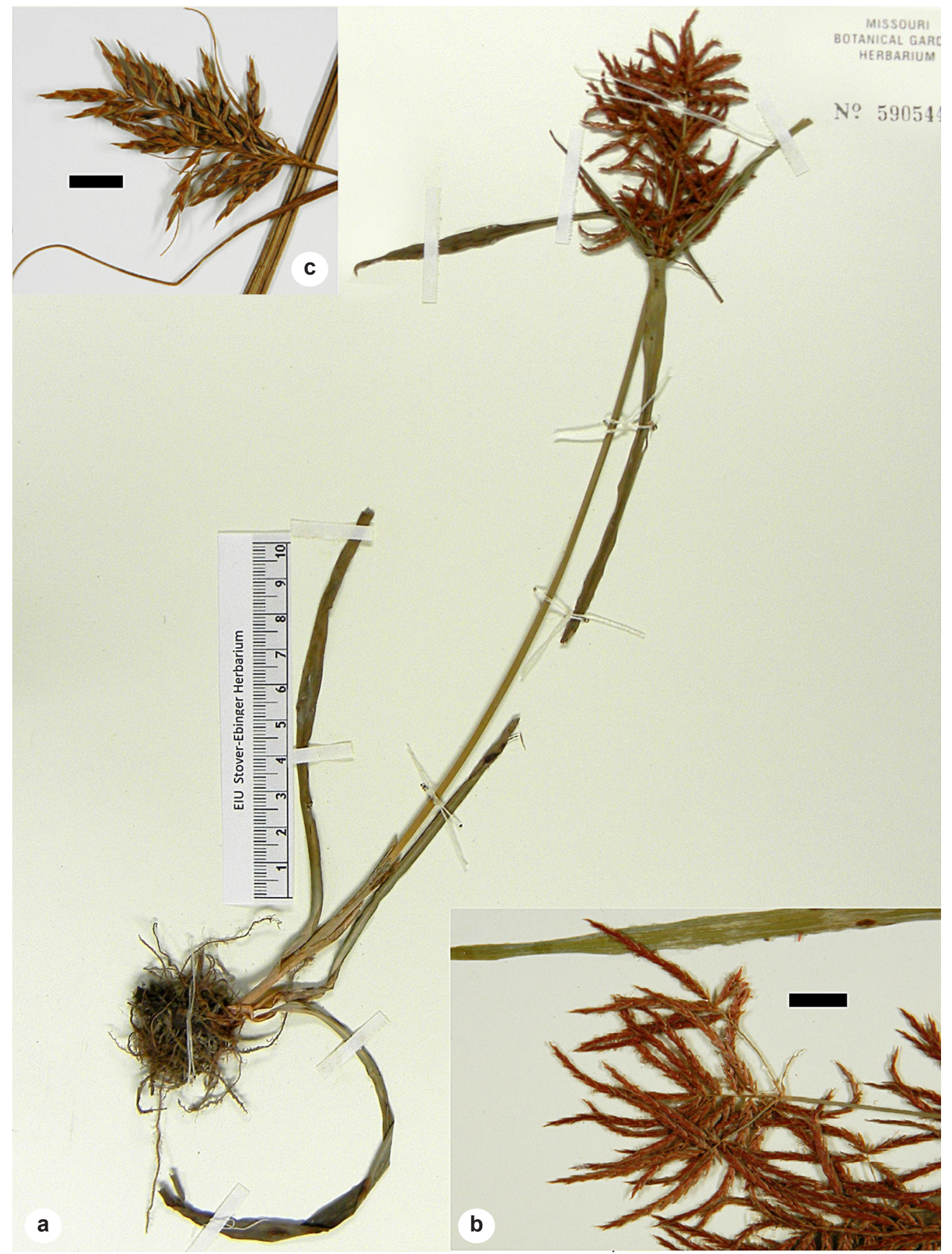

Figure 2 - Cyperus thomasii G.C. Tucker, sp. nov. - a. habit; b. spike, lower right (bar $=5 \mathrm{~mm}$ ); from S.I. Silva s.n. (holotype: NY 00602928; isotype: MO 5905447), from Pernambuco, Brasil. For comparison, c. granatensis C.B. Cl., upper left: spike $(\mathrm{bar}=5 \mathrm{~mm})$ 
Collections might be misidentified as Cyperus rotundus, a common pantropical species, because of the reddish scales. However, C. rotundus has tuber-bearing stolons and lacks a rhizome, and has persistent floral scales, and is not closely related to $C$. sect. Subquadrangulares.

\section{Acknowledgements}

During the course of Neotropical species of Cyperus, some 35,000 herbarium specimens have been borrowed from, or examined at, the herbaria listed below. Thanks are extended to the curators of these institutions, without whose kind cooperation this study would not have been possible: A, AC, AAU, ARIZ, ASU, B, BD, BKL, BH, BM, BR, C, CAS, CHAPA, CO, CONN, CORD, CU, DAO, DAV, DS, DUKE, E, ECON, ENCB, EIU, F, FLAS, FTG, G, GH, ILL, ILLS, IND, JE, K, LCU, LL, M, MICH, MO, MSC, MT, MTMG, NHA, NY, NYS, P, PENN, PH, PMA, POM, PR, PRC, RD, RSA, S, SD, SIU, SMU, SP, TCD, TENN, TEX, TRT, UC, UCR, UEC, UNLV, US, UTEP, VT, WIS, WRSL, WVA, YU, and Z. Thanks also to Marccus Alves and two anonymous reviewers for their helpful comments on the manuscript.

\section{References}

Alves, M.; Araújo, A. C.; Prata, A. P.; Vitta, F.A.; Hefler, S. M.; Trevisan, R.; Gil, A.; Martins, S. \& Thomas, W.W. 2007. Diversidade de Cyperaceae no Brasil. In: Barbosa, L.M. \& Santos, N. A Botânica no Brasil: pesquisa, ensino e políticas públicas ambientais. São Paulo, Sociedade Botânica do Brasil. Pp. 286-290.

IUCN. 2001. IUCN Red List Categories and Criteria: Version 3.1.- IUCN Species Survival Commission. IUCN, Gland \& Cambridge.
Kükenthal, G. 1935-1936. Cyperaceae-ScirpoideaeCypereae. In: Engler, A. Das Pflanzenreich IV. 20 (Heft 101): 1-671.

Larridon, I.; Reynders, M.; Huygh, W.; Bauters, K.; Van de Putte, K.; Muasya, A.M.; Boeckx, P.; Simpson, D.A.; Vrijdaghs, A. \& Goetghebeur, P. 2011a. Affinities in $\mathrm{C}_{3}$ Cyperus lineages (Cyperaceae) revealed using molecular phylogenetic data and carbon isotope analysis. Botanical Journal of the Linnean Society 167: 19-46.

Larridon, I.; Reynders, M.; Huygh, W.; Bauters, K.; Vrijdaghs, A.; Leroux, O.; Muasya, A.M. \& Goetghebeur, P. 2011b. Taxonomic changes in $\mathrm{C}_{3}$ Cyperus (Cyperaceae) supported by molecular phylogenetic data, morphology, embryography, ontogeny and anatomy. Plant Ecology and Evolution 144: 327-356.

McLaughlin, A.D. 1944. The genus Cyperus in the West Indies. Catholic University of America, Biology Studies 5: 1108.

Simpson, D.A. 1989. Taxonomic changes and new taxa in Cyperus, Pycreus and Mariscus. Notes on Brazilian Cyperaceae IV. Kew Bull. 44: 279-287.

Tucker, G.C. 1983. The taxonomy of Cyperus (Cyperaceae) in Costa Rica and Panama. Systematic Botany Monographs 2: 1-85.

Tucker, G.C. 1994. Revision of the Mexican Species of Cyperus L. (Cyperaceae). Systematic Botany Monograph 43: 1-213.

Tucker, G.C. 2001. Cyperus (Cyperaceae). In: Stevens, W.D.; Ulloa, C.; Pool, A.; Montiel, O.M.; Arbeláez, A.L. \& Cutaia, D.M. Flora de Nicaragua. Monograph in Systematic Botany from the Missouri Botanical Garden 85: 740-757.

Tucker, G.C. 2007. Systematics of Cyperus L. section Diffusi Kunth (Cyperaceae) in the Neotropics. In: Barbosa, L.M. \& Santos, N. A Botânica no Brasil: pesquisa, ensino e políticas públicas ambientais. Sociedade Botânica do Brasil, São Paulo. Pp.311-314. 